\title{
Lise Öğrencilerinin Depresyon Düzeylerini Yordayan Değişkenlerin Belirlenmesi: Multinominal Lojistik Regresyon Analizi
}

\section{Selami TANRIVERDI $\dot{I}^{*}$}

Öz: Lise öğrencilerinin depresyon düzeylerinin farklı demografik değişkenler açısından yordanma durumunu ortaya koymak araştırmanın amacını oluşturmaktadır. Araştırmanın çalışma grubunu 2016-2017 eğitim öğretim yılında, Van ili büyükşehir belediye sınırlarında yer alan Tuşba, İpekyolu ve Edremit ilçelerinde seçkisiz yöntemle belirlenen 10 lisede öğrenim görmekte olan lise 11 ve 12. sinıflardan 270 öğrenci (159 k1z, 111 erkek) oluşturmuştur. Nicel verilere dayalı olarak betimsel ve ilişkisel tarama modelinde olan araştırmada, Kısa Semptom Envanteri (KSE) Depresyon alt boyutu, UCLA Yalnızlık ölçeği ve Kişisel Bilgi Formu kullanılmıştır. Katılımcıların ölçme araçlarından almış oldukları puanlar açısından heterojen bir yapı sergileyebilecekleri ve bu anlamda çalışma grubundaki katılımcıların ayrı evrenlerden gelebilme durumlarından hareketle, depresyon bağımlı değişkeni ve yalnızlık bağımsız değişkeni İki Aşamalı Kümeleme (Two-Step Cluster) analizine tabi tutulmuştur. Katılımcıların algıları üzerinde etkili olabilecek yordayıcılar multinominal lojistik regresyon analizi ile modellenmiştir. Multinominal Lojistik Regresyon Analizi sonucunda, yordanan depresyon değişkeni üzerinde; cinsiyet, anne eğitim durumu ve dörtlü kategoriye ayrılmış yalnızlık değişkenleri anlamlı bulunmuştur. Ayrıca lise öğrencilerinin depresyon durumları ile yalnızlık düzeyleri arasında da pozitif yönlü güçlü bir ilişki olduğu tespit edilmiştir.

Anahtar Kelimeler:Lise öğrencileri, depresyon, yalnızlık, lojistik regresyon

\footnotetext{
* Araş. Gör. Van Yüzüncü Yıl Üniversitesi, Eğitim Fakültesi, Rehberlik ve Psikolojik Danışma Anabilim Dalı E-mail: selamitanriverdi@yyu.edu.tr, orcid.org/0000-0003-0845-7219
}

$\begin{array}{lll}\text { Gönderim:17.08.2017 } & \text { Kabul:13.10.2017 } & \text { Yayın:07.11.2017 }\end{array}$




\title{
Determining The Variables Predicted Depression Levels Of High School Students:
}

\section{Multinomial Logistic Regression Analysis}

\begin{abstract}
It is aimed to reveal the predicted circumstance of the depression levels of high
\end{abstract} school students in terms of different demographic variables. The study group of the present study consists of 270 students (159 females, 111 males) from 11th and 12th grade high school students who are randomly selected from 10 different high schools within Tuşba, İpekyolu and Edremit districts of Van province metropolitan municipalities in 2016-2017 education year. Depression subscale of Brief Symptom Inventory (BSI), UCLA Loneliness Scale and Demographic Information Form have been used in the study within descriptive and relational screening model based on quantitative data. As participants may exhibit a heterogeneous structure in terms of the points they have taken from the measurement tools, and in this context as participants in the study group may come from separate universes, depression as a dependent variable and loneliness as an independent variable were analyzed by Two-Step Cluster analysis. The predictors that can be effective on the perceptions of participants were modeled by multinomial logistic regression analysis. As a result of Multinomial Logistic Regression Analysis, on the predicted depression variable; gender, maternal education status and quadruple categorized loneliness variables have been found significant. It has been also found that there is a strong positive relationship between depression status and loneliness levels of high school students.

KeyWords: High school students, depression, loneliness, logistic regression 


\section{Giriş}

Bireyin ruh sağlığı, çevresiyle girdiği çok yönlü ilişkileriyle şekillenmektedir. Yaşantılar, kişinin ruh sağlığını olumlu yönde etkilediği gibi aynı zamanda olumsuz yönde de etkilemektedir. (Ünalan, 2014). Bu açıdan bakıldığında, ruh sağlı̆̆ı kavramının toplumsal ve bireysel gelişim özellikleri dikkate alınarak incelenmesi önemlidir. Bu değişkenler göz önünde tutularak, "Ruh sağlı̆̆1, kişinin var olan gücünü verimli bir biçimde kullanması ve çevresine sağlıklı uyum sağlaması durumu" olarak tanımlanabilir (Bakırcığlu, 2013: s.8).

Sağlıklı ve dengeli uyumu belirleyen temel unsurların da bireyin maruz kaldığı uyarıcılar olduğu söylenebilir. Ancak bireyin dışında gerçekleşen olaylardan kaynaklanan iletiler ve uyaranlar sürekli değişmektedir. Bunların değişmesine bağlı olarak duygu durumlarının da değişmesi kaçınılmazdır. Buradan hareketle birey, içten veya dıştan gelen uyarıcılar nedeniyle kısa süre zarfinda bir duygu durumundan bir diğer duygu durumuna geçebilir. Duygu durumları kişinin iç dünyasıyla ve dış dünyayla etkileşimini olumsuz yönde etkilerse, kısaca ruh sağlığını bozarsa duygu-durum bozukluklarından söz edilir ve son yıllarda duygulanım bozuklukları, depresyonların sebebi olarak görülmekle birlikte (Aktay, 2014), motivasyonu önemli ölçüde düşürerek bireyi, pasif olma eğilimli ve yeni etkileşimlerde bulunmakta güçlük çeken (Atkinson, Atkinson, Smith, Bem, ve Hoeksama, 2002) bir duruma düşürebilmektedir.

Birey günlük yaşamda etkileşimlerinden dolayı farklı duygu durumları yaşayabilmektedir. Çevre ile etkileşim sonucunda ortaya çıkan uyarıcıların birey tarafından değerlendirilmesi, oluşturulacak başa çıkma yönteminin seçilmesinde önemlidir. Eğer söz konusu uyarıcı, birey tarafından biyo-psikososyal denge durumunu bozucu düzeyde bir tehdit olarak algılandıysa anksiyete; kayıp olarak algılandıysa depresyon duygu durumu ortaya 
çıkar(Selye, 1982'den akt., Deniz ve Sümer, 2010). Depresyona ait belirtiler incelendiğinde; enerji kaybı, aktivitelere ve yaşama karşı ilgide düşme, üzüntü, keder, iştah ve kilo kaybı, odaklanma güçlüğü, kendini eleştirme, çaresizlik duyguları, bedensel şikayetler, insanlarla etkileşim kurmakta geri çekilme, sinirlilik, karar verme güçlügü ve intihar etme düşünceleri gibi çok farklı belirtiler olduğu görülmektedir (Aslan, Türkçapar ve Köroğlu, 2009). Ayrıca, depresyon çocukluk yıllarında daha az görülürken, çocukluktan ergenliğe geçişte daha yaygın olarak karşımıza çıkmaktadır. Lisede okuyan öğrencilerin içinde yer aldıkları gelişimsel dönemin özelliği olarak kimlik arayışında olmaları, kendi arkadaş çevreleri içerisinde yer alabilme ve ayrıca okul derslerinde başarılı olabilme girişimleri onları yetişkinlere kıyasla hayata karşı daha hassas ve duyarlı duruma getirebilmektedir (Emiroğlu, Murat ve Bindak, 2011). Bu nedenle ergenlik döneminde sosyal ilişkiler ağında yaşanan sorun veya sorunlar kişinin yaşamını olumsuz etkileyebilmekte ve yalnız hissetmelerine neden olabilmektedir. Nitekim alan-yazın incelendiğinde yalnızlı̆̆ın, tüm yaş grupları tarafından tecrübe edilen, güçlü fakat az anlaşılmış bir risk faktörü olduğu ve ergenler arasında daha yaygın olduğu vurgulanmaktadır (Salimi ve Jowkar, 2011). Kuramsal olarak incelendiğinde, yalnızlık duygusunun ergenlik döneminde önemli bir değişken olarak ele alındığı görülmektedir. Yalnızlık duygusu, yakın çevrede yer alan kişi sayısından ziyade, yaşanan ilişkilerin niteliksel ve niceliksel olarak bireyin düşünce dünyasına uyup uymaması ile bağlantılıdır. Bu nedenle ergenler, yalnızlık duygusunu yetişkin bireylere oranla daha kapsamlı yaşayabilmektedirler (Erözkan, 2004). Buradan hareketle, ergenlerin depresyon ve yalnızlık gibi negatif duygu durumlarından daha çabuk etkilendiği söylenebilir. Ergenlik dönemindeki yalnızlık duygusunu yaşama riski, fiziksel ve sosyal izolasyon deneyimindeki değişiklikler ve her birinin ergenler tarafından farklı düzeylerde algılanması nedeniyle daha şiddetli olmaktadır (Laursen ve Hartl, 2013). Bu bağlamda,ergenlik döneminde yaşanan değişimler, 
ergenin benlik gelişiminde ve sosyal ilişkilerinde de farklılaşmayı beraberinde getirebilir. Ergenin bu farklılaşmayla baş etmeye çalışması, çoğu zaman kendisini ailesi ve etkileşimde bulunduğu diğer kişilerle çatışma yaşamasına sebep olabilmektedir. Bu durumlar kısa vadede ergeni mutsuzluğa iterken, uzun vadede ise ergenin sağlıklı ilişkiler kurmakta zorlanmasına hatta depresyon gibi rahatsılıklar yaşamasına sebep olabilir. $\mathrm{Bu}$ nedenle ergenler için olumsuzluk yaratan duygu durumlarının tanınması ve ergenlerin bu duyguların yaratacağı olumsuzluklardan etkilenmemeleri veya en az düzeyde etkilenmelerini sağlayacak önleyici ve koruyucu çalışmaların yapılması son derece önemlidir.

$\mathrm{Bu}$ çalışma, yukarıda belirtilen nedenlere bağlı olarak ergenlik döneminde bulunan lise öğrencilerinin ruhsal sağlık durumlarına doğrudan etkileri olduğu düşünülen depresyon ve yalnızlık durumlarının tespit edilmesi, karşılıklı olarak incelenmesi ve depresyonu yordayan değişkenlerin belirlenerek bu değişkenlerden hareketle önerilerin geliştirilmesi amac1yla yürütülmüştür.

\section{Yöntem}

$\mathrm{Bu}$ araştırma, genel tarama yöntemlerinden betimsel ve ilişkisel tarama modelindedir. "Tarama modelleri, geçmişte ya da halen var olan bir durumu olduğu şekliyle betimlemeyi amaçlayan araştırma yaklaşımı olup; çok sayıda elemandan oluşan bir evrende, evren hakkında genel bir yargıya varmak amacıyla evrenin tümü ya da evrenden alınacak bir grup üzerinde yapılan tarama düzenlemeleridir. Genel tarama modelinde araştırmaya konu olan durum, kişi ya da nesne, kendi koşulları çerçevesinde ve olduğu gibi tanımlanmaktadır" (Karasar 2014: s. 77).

Çalışma Evreni ve Çalışma Grubu: Araştırmanın çalışma evreni 2016-2017 eğitim öğretim yılı güz yarıyılında Van İli Belediye sınırlarında yer alan Van İli Milli Eğitim Müdürlüğüne bağlı Tuşba, İpekyolu ve Edremit ilçelerinde bulunan liselerde öğrenim gören 
lise 11 ve 12. sınıf öğrencilerinden oluşmaktadır. Belirtilen üç ilçeden birbirine sayı bakımında yakın olacak şekilde, seçkisiz yöntemle belirlenen okullarda öğrenim gören ve araştırmaya gönüllü bir şekilde katılan 270 öğrenci (159 kadın \%58.9, 111 erkek \%41.1) araştırmanın çalışma grubunu oluşturmuştur.

Katılımcılardan elde edilen demografik değişkenler incelendiğinde; katılımcıların yaş dağılımlarında 24 kişinin 16 (\%8.9), 128 kişinin 17 (\%47.4), 92 kişinin 18 (\%34.1), 26 kişinin ise 19 (\%9.6) yaşında olduğu ve katılımcıların eğitim düzeyi incelendiğinde lise 11. sınıfta öğrenim görenlerin sayısının 153 (\%56.7), lise 12. sınıfta öğrenim görenlerin sayısının ise $117(\% 43.3)$ olduğu görülmektedir. Katılımcıların anne eğitim düzeylerine bakıldığında büyük çoğunluğunun 113'nün (\%41.9) okur-yazar olmadığı, 107'sinin (\%39.6) ilkokul mezunu olduğu, 41'inin (\%15.2) ortaokul mezunu olduğu, 7'sinin (2.6) lise mezunu olduğu ve 2'sinin (0.7) ise üniversite mezunu tespit edilmiştir. Katılımcıların baba eğitim düzeyleri incelendiğinde ise büyük çoğunluğunun ilkokul $112(\% 41.5)$ ve lise $62(\% 23)$ mezunlarından oluştuğu, 26'sının (\%9.6) okur-yazar olmadığı, 46'sının (\%17.0) ortaokul mezunu olduğu, 20 'sinin (\%7.4) üniversite mezunu olduğu, 4 (\%1.5) kişinin ise lisansüstü eğitim mezunu olduğu tespit edilmiştir. Katılımcıların herhangi bir yerden psikolojik yardım alıp almadıklarına göre dağılımlarına bakıldığında ise psikolojik destek alanların sayısının 28 (\%10.4) olduğu ve psikolojik yardım almadıklarını ifade eden katılımcı sayısının ise 242 (\%89.6) olduğu görülmüştür.

\section{Veri Toplama Araçları}

Kişisel Bilgi Formu. Araştırmacılar tarafından oluşturulan Kişisel Bilgi Formu ile çalışma grubunda yer alan katılımcılardan kişisel, demografik ve sosyo-kültürel veriler elde etme amaçlanmıştır. Bu amaçla oluşturulan Kişisel Bilgi Formu; yaş, cinsiyet, anne-baba 
eğitim durumu, psikolojik yardım alıp almadığını belirlemeye yönelik sorulardan oluşmaktadir.

Kısa Semptom Envanteri (KSE). Derogatis (1975) tarafından geliştirilen KSE, her faktörde en yüksek yükü alan 53 maddeden oluşmaktadır ve envanter maddeleri "hiç" ve "çok fazla" ifadelerine karşılık gelen 0-4 değerleri arasında derecelendirilmiştir. KSE'nin orijinali; "somatizasyon", "obsesif-kompülsif bozukluk", "kişilerarası duyarlılık", "depresyon", "anksiyete", "hostilite", "fobik anksiyete", "paranoid düşünceler" ve "psikotizm" olmak üzere dokuz alt boyuttan oluşmaktadır (Şahin ve Durak, 1994). KSE'nin Türkçe geçerlik ve güvenilirliği üç ayrı çalışma ile Şahin ve Durak (1994) tarafından yapılmış ve bu çalışmalar sonucunda ölçek, "anksiyete", "depresyon", "olumsuz benlik", "somatizasyon" ve "hostilite" olarak beş faktörden oluşmaktadır. KSE'nde alt gruplardan alınan puanların toplamı ile ulaşılan toplam puan kişinin o alt gruptan aldığı puanı göstermektedir. Toplam puanın artışı sorunun ağırlığının da artışına işaret etmektedir. KSE için bir kesme değeri bulunmamaktadır. Envanterden alınabilecek toplam puan 0-212; alt ölçeklerden alınabilecek puanlar ise sirasıla anksiyete $0-52$; depresyon $0-48$; somatizasyon $0-36$ ve hostilite $0-28$ arasinda değişmektedir (Şahin ve Durak, 1994). Bu araştırmada KSE'nin depresyon alt boyutu kullanılmıştır. Bu çalışma kapsamında KSE'nin depresyon alt boyutuna yönelik yapılan güvenirlik katsayısı çalışmasında Cronbach Alfa'nın .83 olduğu görülmüştür. Nitekim KSE'nin geçerlik ve güvenirliğine ilişkin yapılan çalışmada da depresyon alt boyutu için Cronbach Alfa değerinin .85 olduğu görülmektedir(Şahin, Durak-Batıün ve Uğurtaş, 2002).

\section{UCLA Yalnızlık Ölçeği (University of California Los Angeles Loneliness Scale).} UCLA Yalnızlık Ölçeği ilk defa 1978 yılında Russell, Peplau ve Ferguson (1978) tarafından tüm maddeleri olumsuz ifadeler içeren 20 madde olarak ve dörtlü likert tipinde geliştirilmiştir. Ölçek 1980 yılında Russell, Peplau ve Cutrona (1980) tarafindan tekrar 
gözden geçirilmiş, geçerlik ve güvenirlik çalışmaları yapılmıştır. Yapılan çalışmada ölçeğin maddeleri 10'u düz, 10’u ters olmak üzere 20 madde olarak yeniden düzenlenmiş ve çalışmada ölçeğin Cronbach alfa iç tutarlılık katsayısı .94 olarak tespit edilmiştir. UCLAYalnızlık Ölçeğinin Türkçe geçerlik ve güvenirlik çalışması Demir (1989) tarafından yapılmıştır. Demir'in (1989) ölçek için yaptığı güvenirlik çalışmasında Cronbach Alfa değerinin .96 olduğu görülmektedir. Bu araştırmada ise yapılan güvenirlik katsayısı çalışmasında Cronbach Alfa'nın .90 olduğu görülmüştür.

\section{İşlem ve Veri Analizi}

Araştırmayı yürütebilmek amacıyla alınan yasal izinler ve okul idarecileri ile yapılan işbirliği sonucu uygun görülen tarihlerde okullara gidilmiş, KSE'nin Depresyon alt boyutu ölçeği, UCLA Yalnızlık Ölçeği ve Kişisel Bilgi Formu uygulanmıştır. Uygulama sınıf ortamında ve uygulamaya katılmaya gönüllü olan katılımcılarla yürütülmüştür. Araştırmac1 uygulama esnasında kendisini tanıtmış, yapılan çalışmanın amacı ve veri toplama araçlarının nasıl doldurulması gerektiği ile ilgili bilgi vermiştir. Uygulama esnasında öğrencilerden gelen sorular yanıtlanmıştır. Araştırmacı, veri toplama araçlarını doldurulduktan hemen sonra toplanmıştır. Veri toplama araçları katılımcılar tarafından ortalama 15-20 dakikada doldurulmuştur. Toplanan veriler SPSS istatistik paket programına aktarılarak analiz edilmiştir. Verilerin tek yönlü ve çoklu değişkenli uç değerlerine bakılmış ve katılımcılardan elde edilen 286 veriden 16 tanesi uç değer olduğu için veri setinden çıkarılarak kalan 270 veri ile analizler yapılmıştır. Ölçme araçlarından elde edilen toplam puanların normallik dağılımına Kolmogorov-Smirnov testi ile bakılmıştır. Yapılan analiz sonucunda toplam puanların normal dağıldığı gözlemlenmiştir (p>.05). Katılımcılardan elde edilen veriler; betimleyici, ilişsisel, İki Aşamalı Kümeleme Analizi ve Multinominal Lojistik Regresyon Analizleri kapsamında değerlendirilmiştir. Çalışma grubunda yer alan katılımcıların veri 
toplama araçlarından aldıkları puan bakımından heterojen bir yapı sergileyebilecekleri ve buradan hareketle çalışma grubundaki katılımcıların ayrı evrenlerden gelmiş olma olasılığından dolayı, bağımlı değişken olan depresyon puanları ve bağımsız değişken olan yalnızlık puanları İki Aşamalı Kümeleme (Two-Step Cluster) Analizine tabi tutulmuştur. İki Aşamalı Kümeleme Analizi, heterojen olan yani tek bir evrenden gelmeme şüphesi taşıyan bir örneklemi homojen alt gruplara ayıran ve oluşturulan homojen gruplara ait betimsel ölçüleri farklı bir yoldan hesaplayabilen çok değişkenli istatistiksel analizlerdendir (Kayri, 2007; Tanhan ve Kayri, 2012). Katılımcıların depresyon düzeyleri İki Aşamalı Kümeleme Analizi ile üç kategoriye ayrılmış ve kategoriler üzerinde hangi değişkenlerin yordayıcı olduğunu görmek amacıyla da Multinominal Lojistik Regresyon Analizi yapılmıştır. Lojistik regresyonun en temel amacı, en az değiş̧ken ile en ideal uyumu sağlayacak şekilde, yordayan (bağımsız) ve yordanan (bağımlı) değişkenler arasındaki ilişkiyi açıklayabilen, benimsenecek bir model oluşturmaktır (Atasoy, 2001'den akt., Çokluk, 2010). Ayrıca, "eğer bağımlı değişken ikiden çok kategorili (düzeyli) sınıflamalı bir değişken ise "Çok Kategorili/Düzeyli İsimsel Lojistik Regresyon Analizi (Multinominal Logistic Regression Analysis)” adını alır" (Çokluk, 2010: s.1362). Bu çalışma kapsamında yapılan analizler sonucunda modelin uygunluğu tespit edilmiştir. Araştırma sonuçlarının değerlendirilmesinde 0.05 anlamlılık ile 0.95 önem düzeyi uygun görülmüştür. 


\section{Bulgular}

Depresyon ile yalnızlık toplam puanları arasındaki ilişkiyi belirlemeye yönelik elde edilen veriler Tablo 1'de gösterilmiştir.

Tablo 1.

Depresyon Ölçeği Toplam Puanları İle Yalnızlık Ölçeği Toplam Puanlarının Pearson Korelasyon Analizi Sonuçları

\begin{tabular}{lll}
\hline & & Yalnılık toplam puan \\
\hline Depresyon toplam puan & $\mathrm{r}$ & .627 \\
& $\mathrm{P}$ & .000 \\
& $\mathrm{~N}$ & $\mathbf{2 7 0}$ \\
\hline
\end{tabular}

Tablo 1 incelendiğinde katılımcıların depresyon ile yalnızlık durumları arasında güçlü ve pozitif yönlü ilişki görülmektedir $(\mathrm{r}=.627 ; \mathrm{p}<0.05)$. Buradan hareketle, katılımcıların depresyon düzeyleri yükseldikçe yaşadıkları yalnızlık durumunun da arttığı, diğer bir ifadeyle katılımcıların yalnızlık düzeylerinin artması da yaşadıkları depresyon düzeylerini arttırdığı söylenebilir.

Katılımcıların depresyon ve yalnızlık durumlarını daha detaylı bir şekilde görebilme amacıyla kümeleme analizi yapılmış ve araştırmada katılımcıların depresyon düzeyleri açısından üç farklı evrenden geldikleri tespit edilmiştir. Yalnızlık durumları bakımından ise UCLA Yalnızlık Ölçeğinin dört likertinin her biri bir küme olarak görülmüştür. Çalışma grubundaki heterojenliği ortadan kaldırıp, homojen alt sınıfların oluşturulduğu iki aşamalı kümeleme analizine ilişkin veriler Tablo 2'de görülmektedir.

Tablo 2.

Katılımcılardan Elde Edilen Depresyon ve Yalnızlık Toplam Puanlarının İki Aşamalı Kümeleme Analizi (Two-Step Cluster Analysis) Sonucu

\begin{tabular}{lcccc}
\hline \multicolumn{1}{c}{ Kümeleme (Cluster) } & & & & \\
\hline \multicolumn{1}{c}{ Depresyon } & N & Ortalama $(\mathbf{X})$ & Yüzde (\%) & Standart sapma (ss) \\
\hline 1 (düşük düzeyde depresyon) & 87 & 12.3908 & 32.2 & 3.69901 \\
\hline 2 (orta düzeyde depresyon/eşik) & 127 & 23.6142 & 47.0 & 3.17742 \\
\hline 3 (yüksek düzeyde depresyon) & 56 & 35.1071 & 20.7 & 3.96658 \\
\hline Toplam & 270 & 22.3815 & 100.0 & 8.89002 \\
\hline \multicolumn{1}{c}{ Yalnızlık } & & & 25.2 & 2.27557 \\
\hline 1 (Ben bu durumu hiç yaşamadım) & 68 & 28.5294 & 25.2 & 2.62627 \\
\hline $\begin{array}{l}\text { 2 (Ben bu durumu nadiren } \\
\text { yaşarım) }\end{array}$ & 68 & 36.7059 & & \\
\hline
\end{tabular}




\begin{tabular}{lcccc}
\hline 3 (Ben bu durumu bazen yaşarım) & 89 & 46.9326 & 33.0 & 3.32961 \\
\hline 4 (Ben bu durumu sık sık yaşarım) & 45 & 59.0667 & 16.7 & 3.09985 \\
\hline Toplam & 270 & 41.7444 & 100 & 10.85685 \\
\hline
\end{tabular}

Tablo 2 incelendiğinde, depresyon kategorisinde ikinci kümede yer alan katılımcıların depresyon ölçeği puan ortalamalarının $23.61 \pm 3.17$ olduğu görülmektedir ve bu değer eşik değer olarak bulunmuştur. Orta düzeyde depresyon grubunda 127 (\%47.0) katılımc1 bulunmaktadır. Depresyon ölçek puanı eşik değerinin üstünde olan katılımcılar için depresyonda oldukları, toplam puanı eşik değerin altında olan katılımcılar için ise depresyonda olmadıkları söylenebilecektir. Buna göre Tablo 2'de görüldüğü üzere depresyon kategorisinde birinci kümede toplam puan ortalamaları $12.39 \pm 3.69$ değerinde olan 87 katılımcının depresyonda olmadıkları ve üçüncü kümede yer alan 56 katılımcının ise $35.10 \pm$ 3.96 değerine sahip olarak depresyonda oldukları görülmektedir.

Benzer şekilde Tablo 2 incelendiğinde, yalnızlık ölçeği toplam puanları ölçeğin dörtlü likert tipi göz önüne alınarak katılımcıların yalnızlık durumları benzerliklerine göre dört kümeye ayrılmıştır. Bu bağlamda yalnızlık kategorisinde birinci kümede toplam puan ortalamaları $28.52 \pm 2.27$ değerinde olan 68 katılımcının yalnızlık yaşamadıkları, ikinci kümede toplam puan ortalamaları $36.70 \pm 2.62$ değerinde olan 68 katılımcının ise nadiren yalnızlık yaşadıkları görülmektedir. Yalnızlık üçüncü kümede toplam puan ortalamaları $46.93 \pm 3.32$ değerinde olan 89 katılımcının da bazen yalnızlık durumunu yaşadıkları ancak dördüncü kümede toplam puan ortalamaları $59.06 \pm 3.09$ değerinde olan 45 katılımcının sık sık yalnızlık yaşadıkları görülmektedir.

Araştırmada tahmin edilen modelin, model uyum bilgisi, uyum iyiliği ve pseudo $\mathrm{R}^{2}$ değerleri Tablo 3 'te gösterilmiştir.

Tablo 3.

Model Uyum Bilgisi, Uyum İyiliği ve Pseudo R²

\begin{tabular}{|c|c|c|c|c|c|c|c|}
\hline \multicolumn{3}{|c|}{ Model Uyum Bilgisi } & \multicolumn{3}{|c|}{ Uyum İyiliği } & \multicolumn{2}{|c|}{ Pseudo $R^{2}$} \\
\hline Model & $-2 \mathrm{LL}$ & s.d. & $\chi^{2}$ & s.d. & $\mathbf{p}$ & Cox and Snell & 409 \\
\hline
\end{tabular}




\begin{tabular}{lllll|llll|lll}
\hline Sabit terimli & 459.064 & & & & pearson & 265.905 & 268 & .525 & Nagelkerke & .466 \\
\hline Doymuş & 317.204 & 141.860 & 30 & .000 & Sapma & 241.499 & 268 & .876 & McFadden & .251 \\
\hline
\end{tabular}

Tablo 3 incelendiğinde, model uyum bilgisi ( $\left.\operatorname{LR} \chi^{2}=141.860 ; \mathrm{sd} .=30 ; \mathrm{p}=.000\right)$ ile model uyum iyiliğinde pearson $\left(\chi^{2}=265.905 ;\right.$ sd.=268;p=.525) ve sapma $\left(\chi^{2}=241.499\right.$; sd. $=268 ; p=.876$ ) değerlerine bakıldığında kurulan modelin istatistiksel olarak anlamlı olduğu ve gerçek verilere iyi uyum gösterdiği tespit edilmiştir. Bunun yanı sıra pseudo $\mathrm{R}^{2}$ değerlerinden Cox ve Snell ve Nagelkerke lojistik model tarafından açıklanan varyans miktarını göstermekte ve sonucun 1.00 olması mükemmel model uyumunu ifade etmektedir. Ancak Cox ve Snell $\mathrm{R}^{2}$ hiç bir zaman 1'e ulaşamadığından ve yorumlanması da kolay olmadığ 1 için Nagelkerke $\mathrm{R}^{2}$ hesaplanır (Çokluk, 2010: s.1386). Buradan hareketle Tablo 3'te yer alan pseudo $\mathrm{R}^{2}$ değerlerinin yüksek çıktığı görülmektedir.

Araştırmanın modelinde kullanılan her bir bağımsız değişkenin bağımlı değişkeni bir bütün olarak anlamlı bir şekilde açıklayıp açıklamadığı Tablo 4'te gösterilmiştir.

Tablo 4.

Olabilirlik Oran Testi Sonuçları

\begin{tabular}{lcccc}
\hline \multicolumn{1}{c}{ Etki } & $\begin{array}{c}\mathbf{- 2} \text { Log Likelihood } \\
\text { of Reduced Model }\end{array}$ & $\begin{array}{c}\text { Ki-kare } \\
\left(\boldsymbol{\chi}^{\mathbf{2}}\right)\end{array}$ & $\begin{array}{c}\text { Sd. } \\
(\mathbf{d f} .)\end{array}$ & $\begin{array}{c}\text { Prob. } \\
\text { (Sig.) }\end{array}$ \\
\hline Sabit & $317.204^{\mathrm{a}}$ & .000 & 0 &. \\
\hline Cinsiyet & 325.553 & 8.350 & 2 & .015 \\
\hline Sinıf & 324.753 & 7.549 & 2 & .023 \\
\hline Anne eğitim & 331.673 & 14.469 & 8 & .070 \\
\hline Baba eğitim & 334.010 & 16.806 & 10 & .079 \\
\hline Psikolojik yardım alma & 320.931 & 3.727 & 2 & .155 \\
\hline Yalnızlık dörtlü kategori & 397.882 & 80.678 & 6 & .000 \\
\hline
\end{tabular}

Lojistik regresyon modelinde yer alan bir bağımsız değişkenin anlamlılığını ölçmek için olabilirlik oran testinden yararlanılır. Tablo 4'teki sonuçlar incelendiğinde bağımlı değişken olarak belirlenen depresyon üzerinde bağımsız değişkenlerden cinsiyet $(\mathrm{p}<0.015)$, sinıf $(p<0.023)$ ve yalnızlık dörtlü kategorinin $(p<0.000)$ istatistiksel olarak anlamlı bir etkiye sahip olduğu görülmektedir. Ancak bağımsız değişkenlerden anne eğitim düzeyi ( $p>0.070)$, 
baba eğitim düzeyi ( $>0$ 0.079) ve psikolojik yardım alma değişkenlerinin anlamlı bir etkiye sahip olmadıkları saptanmıştır.

Araştırmanın modeline ilişkin multinominal lojistik regresyon analiz sonuçları Tablo 5'te görülmektedir.

Tablo 5 .

Multinominal Lojistik Regresyon Analizi Sonucu

\begin{tabular}{|c|c|c|c|c|c|c|}
\hline Kategoriler & Depresyon & $\beta$ & Std. Hata & Wald & $\mathbf{P}$ & $\operatorname{Exp}(\beta)$ \\
\hline \multirow{22}{*}{ Düşük } & Sabit & 28.239 & 4975.074 & .000 & .995 & \\
\hline & Cinsiyet (kadın) & -1.211 & .470 & 6.655 & .010 & .298 \\
\hline & Cinsiyet (erkek) & $0^{\mathrm{b}}$ & . & . & . &  \\
\hline & Sinıf (lise 11) & .874 & .469 & 3.479 & .062 & 2.397 \\
\hline & Sinıf (lise 12) & $0^{\mathrm{b}}$ & . & . & . & . \\
\hline & Anne eğitim ok.-yazar değil & -12.951 & 1.795 & 52.044 & .000 & 2.375 \\
\hline & Anne eğitim İlkokul & -13.791 & 1.754 & 61.801 & .000 & 1.025 \\
\hline & Anne eğitim ortaokul & -13.190 & 1.658 & 63.277 & .000 & 1.870 \\
\hline & Anne eğitim lise & 4.501 & 5406.718 & .000 & .999 & 90.065 \\
\hline & Anne eğitim üniversite & $0^{\mathrm{b}}$ & & . & 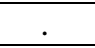 & - \\
\hline & Baba eğitim ok.-yazar değil & -17.321 & 4975.074 & .000 & .997 & 3.004 \\
\hline & Baba eğitim İlkokul & -17.053 & 4975.074 & .000 & .997 & 3.928 \\
\hline & Baba eğitim ortaokul & -17.797 & 4975.074 & .000 & .997 & 1.865 \\
\hline & Baba eğitim lise & -17.435 & 4975.074 & .000 & .997 & 2.680 \\
\hline & Baba eğitim üniversite & -18.652 & 4975.074 & .000 & .997 & 7.933 \\
\hline & Baba eğitim lisansüstü & $0^{\mathrm{b}}$ & & $\cdot$ & & 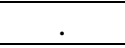 \\
\hline & Psikolojik yardım (evet) & -1.192 & .880 & 1,836 & .175 & .304 \\
\hline & Psikolojik yardım (hayır) & $0^{\mathrm{b}}$ & $\cdot$ & . & $\dot{\square}$ & . \\
\hline & Yalnızlık (hiç yaşamadım) & 5.825 & 1.096 & 28,227 & .000 & 338.494 \\
\hline & Yalnızlık(nadiren yaşarım) & 4.085 & .936 & 19,061 & .000 & 59.468 \\
\hline & Yalnızlık (bazen yaşarım) & 2.172 & .865 & 6.303 & .012 & 8.778 \\
\hline & Yalnızlık (sık sık yaşarım) & $0^{\mathrm{b}}$ & . & . & 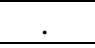 & . \\
\hline \multirow{20}{*}{ Orta } & Sabit & 31.751 & 4975.074 & .000 & .995 & \\
\hline & Cinsiyet (kadın) & -.330 & .386 & .730 & .393 & .719 \\
\hline & Cinsiyet (erkek) & $0^{\mathrm{b}}$ & - & . & & . \\
\hline & Sinıf (lise 11) & -.093 & .373 & .062 & .803 & .911 \\
\hline & Sinıf (lise 12) & $0^{\mathrm{b}}$ & . & . & - & $\cdot$ \\
\hline & Anne eğitim ok.-yazar değil & -14.026 & .655 & 458.509 & .000 & 8.101 \\
\hline & Anne eğitim İlkokul & -14.634 & .591 & 612.858 & .000 & 4.410 \\
\hline & Anne eğitim ortaokul & -14.903 & .000 & . & 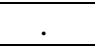 & 3.371 \\
\hline & Anne eğitim lise mezunu & .024 & 5406.718 & .000 & 1.000 & 1.024 \\
\hline & Anne eğitim üniversite & $0^{\mathrm{b}}$ & - & . & - & . \\
\hline & Baba eğitim ok.-yazar değil & -17.785 & 4975.074 & .000 & .997 & 1.888 \\
\hline & Baba eğitim İlkokul & -17.309 & 4975.074 & .000 & .997 & 3.038 \\
\hline & Baba eğitim ortaokul & -17.333 & 4975.074 & .000 & .997 & 2.967 \\
\hline & Baba eğitim lise & -17.287 & 4975.074 & .000 & .997 & 3.107 \\
\hline & Baba eğitim üniversite & -15.849 & 4975.074 & .000 & .997 & 1.309 \\
\hline & Baba eğitim lisansüstü & $0^{\mathrm{b}}$ &. &. & . &. \\
\hline & Psikolojik yardım (evet) & -.851 & .485 & 3.082 & .079 & .427 \\
\hline & Psikolojik yardım (hayır) & $0^{\mathrm{b}}$ & . & . & 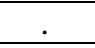 & . \\
\hline & Yalnızlık (hiç yaşamadım) & 2.463 & .836 & 8.681 & .003 & 11.742 \\
\hline & Yalnızlık(nadiren yaşarım) & 2.210 & .586 & 14.227 & .000 & 9.118 \\
\hline
\end{tabular}




\begin{tabular}{ccccccc}
\hline Yalnızlık (bazen yaşarım) & 1.048 & .425 & 6.075 & .014 & 2.853 \\
\cline { 2 - 7 } & Yalnızlık (sık sık yaşarım) & $0^{\mathrm{b}}$ &. &. &. &. \\
\hline
\end{tabular}

Referans kategorisi: Yüksek depresyon

Tablo 5 incelendiğinde bağımlı değişken olarak belirlenen depresyon puanları multinominal lojistik regresyon modeline düşük, orta ve yüksek depresyon olarak dahil edildi. "Yüksek depresyon kategorisi" referans değeri olarak alındığında, düşük depresyon kategorisinde katılımcıların depresyon puanlarını cinsiyeti kadın olan, anne eğitim durumu okur yazar değil, anne eğitim durumu ilkokul, anne eğitim durumu orta okul ile katılımcıların yalnızlık değerleri $\beta$ kat sayıları ve Wald istatistiği dikkate alınarak değerlendirildiğinde anlamlı düzeyde yordayıcı değişkenler oldukları görülmektedir. Buna göre depresyon düşük kategorisinde önem sirasına göre yer alan anne eğitim durumu orta okul ( $\beta=-13.190$; Wald= 63.277; $\mathrm{p}<.01)$, anne eğitim durumu ilkokul $(\beta=-13.791 ; \mathrm{Wald}=61.801 ; \mathrm{p}<.01)$, anne eğitim okur yazar olmayan $(\beta=-12.951 ;$ Wald $=52.044 ; \mathrm{p}<.01)$, yalnılılk durumunu hiç yaşamayan $(\beta=5.825 ; \mathrm{Wald}=28.227 ; \mathrm{p}<.01)$, yalnızlık durumunu nadiren yaşayan $(\beta=4.085 ; \mathrm{Wald}=$ $19.061 ; \mathrm{p}<.01)$, cinsiyeti kadın olan $(\beta=-1.211 ; \mathrm{Wald}=6.665 ; \mathrm{p}<.01)$ ve yalnızlık durumunu bazen yaşayan $(\beta=2.172 ; \mathrm{Wald}=6.303 ; \mathrm{p}<.05)$ değişkenleri lise öğrencilerinin depresyon düzeyleri üzerinde etkiye sahiptirler. Ancak anne eğitim durumu lise olma, baba eğitim durumunun tüm kademeleri değişkenlerinin Wald değerleri .000 değeri taşımakta bu durumda istatistiksel olarak analizde gereksiz olarak değerlendirilmekte ve bu değișkenlerin lise öğrencilerinin depresyon düzeyleri üzerinde herhangi bir etkiye sahip olmadıklarını göstermektedir. Psikolojik yardım alma durumu $(\beta=-1.192 ; \mathrm{Wald}=1.836 ; \mathrm{p}>0.05)$ ve lise 11 . sınıfta okuma $(\beta=.874 ;$ Wald $=3.479 ; \mathrm{p}>.05)$ değişkenleri de istatistiksel olarak anlamlı bulunmamıştır.

Tablo 5'te "Yüksek depresyon kategorisi" referans değeri olarak alındığında, orta depresyon kategorisinde katılımcıların depresyon puanlarını anne eğitim durumu okur yazar değil, anne eğitim durumu ilkokul ile katılımcıların yalnızlık değerleri $\beta$ kat sayıları ve Wald 
istatistiği dikkate alınarak değerlendirildiğinde anlamlı düzeyde yordayıcı değişkenler oldukları görülmektedir. Buna göre, depresyon orta kategorisine bakıldığında, önem sırasına göre yer alan anne eğitim ilkokul $(\beta=-14.634$;Wald= 612.858; $p<.01)$, anne eğitim okur yazar olmayan $(\beta=-14.026 ;$ Wald $=458.509 ; \mathrm{p}<\quad .01)$, yalnızlık durumunu nadiren yaşayan $(\beta=2.210 ; \mathrm{Wald}=14.227 ; \mathrm{p}<.01)$, yalnızlık durumunu hiç yaşamayan $(\beta=2.463 ; \mathrm{Wald}=8.681$; $\mathrm{p}<.01)$ ve yalnızlık durumunu bazen yaşayan $(\beta=1,048 ;$ Wald $=6,075 ; \mathrm{p}<.05)$ değişkenleri lise öğrencilerinin depresyon düzeyleri üzerinde etkisi vardır. Ancak anne eğitim durumu lise olma, baba eğitim durumunun tüm kademeleri değişkenlerinin Wald değerleri .000 değeri taşımakta bu durumda istatistiksel olarak analizde gereksiz olarak değerlendirilmektedir. $\mathrm{Bu}$ durum belirtilen değişkenlerin öğrencilerin depresyon düzeyleri üzerinde herhangi bir etkiye sahip olmadıklarını göstermektedir. Ayrıca depresyon orta kategoride yer alan cinsiyeti kadın olan $(\beta=-.330 ;$ Wald=.730; $p>0.05)$, lise 11. sinıfta okuma $(\beta=-.093 ;$ Wald $=.062 ; p>0.05)$ ve psikolojik yardım alma $(\beta=-.851 ;$ Wald= 3.082; $\mathrm{p}=.079)$. değişkenleri de istatistiksel olarak anlamlı bulunmamıştır.

Araştırmada istatistiksel olarak anlamlı bulunmayan değişkenler modelden çıkartılmamıştır. Anlamlı bulunmayan değişkenler, modelin güvenirliğini etkilememekte ve modelde $\mathrm{p}<0.05$ anlamlılık düzeyine göre, istatistiksel olarak anlamsız bulunan değişkenlere ait p değerleri ikili karşılaştırma sonuçlarını ifade etmektedir. Ayrıca modelin bütünsel olarak anlamlılığı üzerinde bir etkisi bulunmamaktadır. 


\section{Tartışma, Sonuç ve Öneriler}

$\mathrm{Bu}$ araştırmada lise öğrencilerinin depresyon durumlarının yordanmasında belirleyici olabilecek bazı değişkenler Multinominal Lojistik Regresyon Analizi ile modellenmiştir. Öncelikle araştırmada, depresyon bağımlı değişkeni ve yalnızlık bağımsız değişkeni İki Aşamalı Kümeleme (Two-Step Cluster) analizine tabi tutulmuştur. Analizler sonucunda, depresyon puanları için katılımcıların \%32.2'si düşük depresyon, \%20.7'sinin ise yüksek depresyon kümesinde yer aldıkları görülmektedir. Geriye kalan oran ise depresyonda orta seviyede (eşik) olduğu görülmüştür. Yalnızlık puanları için ise ölçeğin dörtlü likert tipi dikkate alınarak yapılan analizde katılımcıların \%25.2'sinin yalnızlığı hiç yaşamadıkları, \%25.2'sinin yalnızlığı nadiren yaşadıkları, \%33'ü yalnızlığı bazen yaşadıkları, \%16.7'si ise yalnızlığı sık sık yaşadıkları görülmüştür. Katılımcıların algıları üzerinde etkili olabilecek yordayıcıları belirlemeye yönelik yapılan Multinominal Lojistik Regresyon Analizi sonucunda, "yüksek depresyon kategorisi" referans değer olarak alındığında, düşük depresyon kategorisinde yordanan değişken üzerinde önem sırasına göre; anne eğitim durumu ortaokul, anne eğitim durumu ilkokul, anne eğitim durumu okuryazar olmayan, yalnızlık durumunu hiç yaşamayan, yalnızlık durumunu nadiren yaşayan, cinsiyeti kadın olan, yalnızlık durumunu bazen yaşayan değişkenleri anlamlı bulunmuştur. Orta depresyon kategorisinde ise önem sırasına göre; anne eğitim durumu ilkokul, anne eğitim durumu okur yazar olmayan, yalnızlık durumunu nadiren yaşayan, yalnızlık durumunu hiç yaşamayan ve yalnızlık durumunu bazen yaşayan değişkenleri, yordanan değişken üzerinde anlamlı bulunmuşlardır.

Katılımcıların depresyon düzeyleri ile yalnızlık durumları arasında yapılan pearson korelasyon testi sonucunda ortalamanın üzerinde pozitif yönlü $(r=.627 ; \mathrm{p} \leq .000)$ anlamlı bir 
ilişki tespit edilmiştir. Yani katılımcıların depresyon düzeylerindeki artış yalnızlık durumlarını, yalnızlık durumlarındaki artış ise depresyon düzeylerini artırdığı söylenebilir. Ayrıca Multinominal Lojistik Regresyon Analizi sonucunda yüksek depresyon kategorisi referans alındığında hem düşük depresyon kategorisi hem de orta depresyon kategorilerinde de yalnızlık değişkeninin, katılımcıların depresyon durumları üzerinde anlamlı yordayıcı olduğu görülmüştür. Nitekim Ladd ve Ettekal'ın (2013) araştırmalarında, yalnızlık ile depresyonun kısmen belirgin fakat ilişkili yapılar olduğu ve ergenlerden daha fazla yalnızlık hissettiğini ifade edenlerin, daha çok sayıda depresif belirtiyi ortaya koyma eğilimi gösterdikleri görülmüştür. Benzer şekilde bu bulguyu destekleyici farklı çalışmalarda bulunmaktadır (Qualter ve diğ., 2013; Qualter, Brown, Munn, ve Rotenberg, 2010).

$\mathrm{Bu}$ araştırmada, cinsiyet değişkeninin katılımcıların depresyon puanları üzerinde anlamlı yordayıcı olduğu görülmüştür. Buna göre cinsiyeti kadın olan katılımcıların depresyon düzeyi, cinsiyeti erkek olan katılımcılara göre daha yüksek bulunmuştur. Literatür incelendiğinde bu bulguyu destekleyici çalışmalar görülmektedir (Emiroğlu, Murat ve Bindak, 2011; Eskin, Ertekin, Harlak ve Dereboy, 2008; Öztop ve diğ., 2011; Pektaş, 2015; Yolalan, 2013). Fakat literatürde cinsiyet değişkeni ile depresyon arasında anlamlı farkın olmadığı çalışmalarda bulunmaktadır(Ören ve Gençdoğan, 2007; Özdel, Bostancı, Özdel ve Oğuzhanoğlu, 2002;Üstün ve Bayar, 2015).

Araştırma bulgularında, yüksek depresyon kategorisi referans alındığında, hem düşük depresyon kategorisi hem de orta depresyon kategorilerinde anne eğitim durumu değişkeninin katılımcıların depresyon puanları üzerinde anlamlı yordayıcı olduğu tespit edilmiştir. Fakat, anne eğitim durumunu lise ve üniversite olarak belirten katılımcıların sayısının diğerlerine oranla çok az olmasının da etkisi olabileceği göz önüne alınarak; anne eğitim durumu okuryazar olmayan, anne eğitim durumu ilkokul olan ve anne eğitim durumu ortaokul olan 
katılımcıların depresyon düzeyleri, anne eğitim durumu lise olan ve anne eğitim durumu üniversite olan katılımcılara göre daha yüksek bulunmuştur. Buradan hareketle annenin eğitim durumunun yüksek olması, ergenlik döneminde bulanan lise öğrencisini daha iyi anlamaya ve daha sağlıklı bir iletişim kurmaya olanak sağladığı söylenebilir. Nitekim, ÇamÇelikel ve Erkorkmaz'ın (2008) yaptıkları çalışmada da anneleri düşük öğrenim düzeyinde olan öğrencilerin depresyon puanlarının, anneleri lise ve üzeri öğrenime sahip öğrencilere göre daha yüksek olduğu tespit edilmiştir. Benzer şekilde bu bulguyu destekleyen farklı çalışmalar da bulunmaktadır (Türkleş, Hacıhasanoğlu ve Çapar, 2008). Fakat literatürde anne eğitim durumu ile öğrencilerin depresyon düzeyleri arasında anlamlı farkın bulunmadığg çalışmalarda bulunmaktadır (Sancakoğlu ve Sayar, 2012; Yolalan, 2013).

Araştırma bulgularından sınıf, baba eğitim durumu ve psikolojik destek alma durumu değişkenlerinin lise öğrencilerinin depresyon düzeyleri üzerinde anlamlı yordayıcılar olmadıkları görülmüştür. Çalışma grubuna sadece lise 11 ve 12. sınıf öğrencileri dahil edildiğinden dolayı yaş farkının fazla olmaması ve yaşanılan duygu-durum yoğunluğunun benzer olma olasılığından dolayı depresyon düzeyleri arasında farklılığın oluşmadığı düşünülmektedir. Sınıf değişkenine ilişkin alan-yazında bu bulguyu destekleyici çalışmalara rastlanmaktadır. (Tezel ve diğ., 2009; Türkleş ve diğ., 2008). Fakat literatürde sınıf değişkeni ile depresyon arasında anlamlı farkın bulunduğu çalışmalar da bulunmaktadır (Ören ve Gençdoğan, 2007). Baba eğitim durumu değişkeninin öğrencilerin depresyon düzeylerini yordamamasının nedeni olarak; babanın çalışıyor olması, anneye kıyasla çocukları ile daha az zaman geçirmesi ve bu durumun sonucu olarak da baba ile ergen arasında daha az çatışma yaşanabilme olasılığının etkili olduğu düşünülmektedir. Literatür incelendiğinde destekleyici çalışmalar görülmektedir (Emiroğlu ve diğ., 2011; Özdel ve diğ., 2002; Sancakoğlu ve Sayar, 2012; Yolalan, 2013). Fakat, tıp öğrencileri ile yapılan bir çalışmada babanın eğitim düzeyi 
artıkça öğrencilerde depresif belirtilerinde arttığı tespit edilmiştir (Kaya, Genç, Kaya ve Pehlivan, 2007). Bu araştırmada, psikolojik destek alma durumu değişkeninin öğrencilerin depresyon düzeylerini anlamlı şekilde yordamamasının nedeni olarak, psikolojik destek aldıklarını belirten kişi sayısının az olmasının etkili olduğu düşünülmektedir. Bu çalışmada, sadece 28 katılımcı psikolojik destek aldıklarını belirtmişlerdir. Nitekim literatür incelendiğinde, öğrencilerin problemleriyle baş edebilmek için bir ruh sağlığı uzmanı dışında ilk olarak ailelerine ve arkadaşlarına yöneldikleri ve ayrıca, öğrencilerin bir ruh sağlı̆gı uzmanından psikolojik destek alma niyetlerinin de düşük düzeyde olduğu görülmüştür (Topkaya ve Meydan, 2013).

Sonuç olarak, hem fiziksel değişim hem de psikolojik olarak duygu-durum değişiminin yaşandığı ergenlik döneminde, ergenlerin yaşadıkları depresyon ve yalnızlık gibi duygu durumlarının üstesinden gelebilmeleri için liselerde, ergen-aile etkileşiminin geliştirilmesine yönelik etkinlikler düzenlenebilir. Bu bağlamda, okul rehberlik hizmetlerinin ergenlik döneminde ön plana çıkan depresyon ve yalnızlık gibi duygu durumlarıyla ilgili önleyici çalışmalarda doğrudan depresyon ve yalnızlık duygu durumlarına üzerinde yoğunlaşmaktansa dolaylı olarak duygularını ve düşüncelerini ifade etme, güçlü ve zayıf yönlerinin farkında olma, empatik davranışlar geliştirme, etkinliklere katılmaya gönüllü olma, iletişim becerilerini geliştirme ve işbirliğine dayalı etkinliklerde yer alma gibi kişisel rehberlik etkinliklerine yer verilebilir. Lise öğrencilerinin depresyon ve yalnızlık durumlarıyla daha kolay baş edebilmeleri amacıyla okul arkadaşlarıyla olumlu ilişkiler kurabilmeleri için birlikte sosyal ve kültürel aktiviteler düzenleme, grup çalışmaları, grupla işbirliğinde bulunma gibi becerilerini geliştirmeye yönelik aktiviteler yapılabilir. Benzer şekilde lise öğrencilerinin depresyon gibi duygu durumlarına ilişkin konularda yapılacak kapsamlı araştırmalar ile yoğun depresyon yaşayan öğrencilerin kişisel ve sosyal özelliklerini 
belirlemeye yönelik çalışmalar alan yazına önemli katkılar sağlayacaktır. Bu kapsamda, lise öğrencilerinden yoğun olarak depresyon duygu durumunu yaşayanların belirlenerek öğrenciokul-aile birlikteliğinin olduğu kültüre özgü deneysel araştırmalar hazırlayarak, bu araştırmaların kısa ve uzun vadede etkililiğinin test edilmesinin ve araştırılmasının önemli olduğu düşünülmektedir.

\section{Makalenin Bilimdeki Konumu (Yeri)}

Eğitim Bilimleri Bölümü/ Rehberlik ve Psikolojik Danışma Anabilim Dalı

\section{Makalenin Bilimdeki Özgünlüğü}

Lise dönemi, ergenlik çağına denk gelmektedir. Bu gelişim evresinde ergenlerin yaşadıkları duygu-durum değişiminin etkilerinin bilinmesi yapılacak önleyici çalışmalar için önem arz etmektedir. Bu nedenle ergenler için olumsuzluk yaratan depresyon ve yalnızlık gibi duygu durumlarının tanınması ve bu duygu durumlarının yaratacağı olumsuzlukları önlemeye yönelik çalışmalara ihtiyaç duyulmaktadır. Buradan hareketle ergenlerin psikolojik iyilik hallerine doğrudan etkileri olduğu düşünülen depresyon ve yalnızlık duygu-durumları ile ilgili yapılan bu çalışmada, ele alınan değişkenlerden elde edilen veri sonuçlarının alan yazına önemli katkılar sağlayacağı düşünülmektedir. Ayrıca, kişinin yaşamını birçok açıdan olumsuz yönden etkileyebilen depresyonun, farklı değişkenlerle ele alınmış olması ve anlamlı bulguların elde edilmesi çalışmanın özgünlüğüne katkı sağlamaktadır. 


\section{Kaynakça}

Aktay, M. (2014). Üniversite öğrencilerinde aleksitimi ve depresyonun yordayıcısı olarak bağlanma stilleri. (Yayımlanmamış yüksek lisans tezi, İstanbul Üniversitesi, Sosyal Bilimler Enstitüsü, İstanbul). https://tez.yok.gov.tr/UlusalTezMerkezi adresinden edinilmiştir.

Atkinson, R. L.; Atkinson, R. C.; Smith, E. E.; Bem, D. J. \& Hoeksama, S. N. (2002). Psikolojiye giriş (Çev: Y. Alogan). (3. Baskı). Ankara: Arkadaş Yayınları.

Bakırcıoğlu, R. (2013). Çocuk ve ergende ruh sağlığı. (Genişletilmiş 5. Baskı). Ankara: Anı Yayınc1lik.

Çam-Çelikel, F. ve Erkorkmaz, U. (2008).Üniversite öğrencilerinde depresif belirtiler ve umutsuzluk düzeyleri ile ilişkili etmenler. Archives Of Neuropsychiatry/ Noropsikiatri Arsivi, 45(4), 122-129.

Çokluk, Ö. (2010). Lojistik regresyon analizi: kavram ve uygulama. Kuram ve Uygulamada Eğitim Bilimleri.10(3),1357-1407.

Demir, A. (1989). UCLA Yalnızlık Ölçeği'nin geçerlik ve güvenirliği. Psikoloji dergisi, 7(23), 14-18.

Deniz M. E. ve Sümer A. S. (2010) Farklı özanlayış düzeylerine sahip üniversite öğrencilerinde depresyon, anksiyete ve stresin değerlendirilmesi. Eğitim ve Bilim.35(158),115-127.

Emiroğlu, M., Murat, M., ve Bindak, R. (2011). Lise son sınıf öğrencilerinin depresyon düzeylerini yordayan sosyo-demografik değişkenlerin belirlenmesi. Elektronik Sosyal Bilimler Dergisi,10(38), 262-274.

Erözkan, A. (2004). Lise öğrencilerinin bağlanma stilleri ve yalnızlık düzeylerinin bazı değişkenlere göre incelenmesi. Atatürk Üniversitesi Sosyal Bilimler Enstitüsü Dergisi, 4(2), 155-175.

Eskin, M., Ertekin, K., Harlak, H. ve Dereboy, Ç. (2008). lise öğrencisi ergenlerde depresyonun yaygınlığı ve ilişkili olduğu etmenler. Türk Psikiyatri Dergisi, 19(4),382-389.

Karasar, N. (2014). Bilimsel araştırma yöntemi (26. Baskı). Ankara: Nobel Akademik Yayıncılık. 
Kaya, M., Genç, M., Kaya, B. ve Pehlivan, E. (2007). Tıp fakültesi ve sağlık meslek yüksekokulu öğrencilerinde depresif belirti yaygınlığı, stresle başa çıkma tarzları ve etkileyen faktörler. Türk Psikiyatri Dergisi, 18(2), 137-146.

Kayri, M. (2007). Araştırmalarda İki Aşamalı Kümeleme (Two-Step Clustering) Analizi ve Bir Uygulamas1. Eurasian Journal of Educational Research (EJER), 28 (1),89-99.

Ladd, G. W., \& Ettekal, I. (2013) Peer-related loneliness across early to late adolescence: Normative trends, intra-individual trajectories, and links with depressive symptoms. Journal of Adolescence 36(6),1269-1282. DOI:10.1016/j.adolescence.2013.05.004

Laursen, B., \& Hartl, A. C. (2013) Understanding loneliness during adolescence: Developmental changes that increase the risk of perceived social isolation. Journal of Adolescence 36:1261-1268. DOI:10.1016/j.adolescence.2013.06.003

Leahy, R. L., \& Holland, S. J. (2009). Depresyon ve anksiyete bozukluklarında tedavi planları ve girişimleri. (S, Aslan, H, Türkçapar ve E, Köroğlu Çev.). Ankara: Hyb Basim.

Ören, N. ve Gençdoğan, B. (2007). Lise öğrencilerinin depresyon düzeylerinin baz1 değişkenlere göre incelenmesi. Kastamonu Ĕ̆itim Dergisi, 15(1), 85-92.

Özdel, L., Bostanc1, M., Özdel, O., ve Oğuzhanoğlu, N. K. (2002). Üniversite öğrencilerinde depresif belirtiler ve sosyodemografik özelliklerle ilişkisi. Anadolu Psikiyatri Dergisi, 3(3), 155-161.

Öztop, D.B., Öztürk, A., Ünalan, D., Mazıcıoğlu, M., Balcı, E. ve Gün, İ. (2011). Lise öğrencilerinde depresyon ve davranış sorunlarının $\quad$ yaygınlığı. Anadolu Psikiyatri Dergisi,12(3), 204-211.

Pektaş, E. (2015). Üniversite öğrencilerinin algıladıkları ebeveyn kabul- reddi ile depresyon ve sürekli kaygı düzeyleri arasındaki ilişkinin incelenmesi: duygu düzenleme güçlüklerinin aracı rolü. (Yayımlanmamış yüksek lisans tezi, Hacettepe Üniversitesi/Sosyal Bilimler Enstitüsü, Ankara). http://hdl.handle.net/11655/1332

Qualter, P., Brown, S. L., Munn, P., \& Rotenberg, K. J. (2010). Childhood loneliness as a predictor of adolescent depressive symptoms: an 8-year longitudinal study. European Child \& Adolescent Psychiatry, 19(6), 493-501. http://dx.doi.org/10.1007/s00787009-0059-y

Qualter, P., Brown, S.L., Rotenberg, K.J., Vanhalst, J, Harris, R.A., Goossens, L., M. Bangee\& Munn, P. (2013). Trajectories of loneliness during childhood and 
adolescence: predictors and health outcomes. Journal of Adolescence. 36(6), 12831293. https://doi.org/10.1016/j.adolescence.2013.01.005

Russell, D , Peplau, L. A.., \& Cutrona, C. E. (1980). The Revised UCLA Loneliness Scale: Concurrent and discriminate validity evidence. Journal of Personality and Social Psychology, 39(3), 472-480.

Russell, D., Peplau, L. A. \& Ferguson, M. L. (1978). Developing a measure of loneliness. journal of personality assessment, 42(3), 290- 294. http://dx.doi.org/10.1207/s15327752jpa4203_11

Salimi, A., \& Jowkar, B. (2011) Personality predispositions and loneliness in adolescence. international conference on education and educational psychology. Procedia - Social and Behavioral Sciences,29,296-299. https://doi.org/10.1016/j.sbspro.2011.11.242

Sancakoğlu, S., ve Sayar, M. (2012). Relation between socioeconomic status and depression, anxiety, and self-esteem in early adolescents. New/Yeni Symposium, 50(4), 207-220.

Şahin, N.H. ve Durak, A. (1994). Kısa Semptom Envanteri'nin (Briaf Symptom InventoryBSI) Türk gençleri için uyarlanması, Türk Psikoloji Dergisi, 9(31), 44-56.

Şahin, N. H., Batıgün, A. D. ve Uğurtaş, S. (2002). Kısa Semptom Envanteri (KSE): Ergenler için kullanımının geçerlik, güvenilirlik ve faktör yapısı. Türk Psikiyatri Dergisi, 13(2), 125-135.

Tanhan, F. ve Kayri, M. (2012). Öğretmen adaylarının üniversite öğretim elemanlarına yönelik algılarını etkileyen faktörlerin chaid analizi ile incelenmesi. Kuram ve Uygulamada Ĕ̈itim Bilimleri, 12(2), 807-821.

Tezel, A., Arslan, S., Topal, M., Aydoğan, Ö., Koç, Ç. ve Şenlik, M. (2009). Hemşirelik öğrencilerinin problem çözme becerileri ve depresyon düzeylerinin incelenmesi. Atatürk Üniversitesi Hemşirelik Yüksekokulu Dergisi, 12 (4), 1-10.

Topkaya, N. ve Meydan, B. (2013).Üniversite öğrencilerinin problem yaşadıkları alanlar, yardım kaynakları ve psikolojik yardım alma niyetleri. Trakya Üniversitesi Eğitim Fakültesi Dergisi, 3(1), 25- 37.

Türkleş S, Hacıhasanoğlu R. ve Çapar S.(2008). Lise öğrencilerinde depresyon düzeyi ve etkileyen faktörlerin incelenmesi. Atatürk Üniversitesi Hemşirelik Yüksekokulu Dergisi,11(2),18-28.

Ünalan, E. (2014). Üniversite öğrencilerinde ruh sağlığı, sağlık kaygısı ve sağlık davranışları arasındaki ilişkiler. (Yayımlanmamış yüksek lisans tezi, Okan Üniversitesi/Sosyal 
Bilimler Enstitüsü, İstanbul). https://tez.yok.gov.tr/UlusalTezMerkezi adresinden edinilmiştir.

Üstün, A ve Bayar, A. (2015). Üniversite öğrencilerinin depresyon, anksiyete ve stres düzeylerinin çeşitli değişkenlere göre incelenmesi.Eğitim ve Öğretim Araştırmaları Dergisi, 4(1), 384-390. ISSN: 2146-9199

Yolalan, H. (2013). Ergenlerde depresyon ve bağlanma stilleri arasındaki ilişkinin incelenmesi. (Yayımlanmamış yüksek lisans tezi, İstanbul Arel Üniversitesi/Sosyal Bilimler Enstitüsü, İstanbul). http://193.255.56.45:8080/xmlui/handle/123456789/140

\section{Summary}

Problem Statement:The efforts of high school students to find their own identities, to be able to exist in their friends' environments and at the same time to succeed in their lessons at their current age are making them more susceptible to life than adults (Emiroğlu, Murat \& Bindak, 2011). Therefore, the problems or issues in the network of social relations during adolescence can negatively affect one's life and cause them to feel alone.In the literature, it is said that adolescents are influenced more quickly from negative emotional states such as depression and loneliness. The risk of loneliness during adolescence is more severe because of the changes in the experience of physical and social isolation, and because each one is perceived at different levels by the adolescents (Laursen \& Hartl, 2013). In this context, many changes in adolescence can bring about differentiation of the adolescent in self development and social relations. Trying to cope with this differentiation of the adolescent can often lead to conflict with his/her family and other people with whom he/she has interaction. While these situations push the student to unhappiness in the short term, the adolescent may have difficulty in establishing healthy relationships and may even cause illnesses such as depression in the long period. Thus it is extremely important to conduct studies to recognize depression and loneliness emotions that are negative for adolescents and 
to prevent adolescents from being affected by the adversities caused by these feelings or to prevent them from being affected at a minimum level.

Purpose of the Study:The purpose of this study is to determine the depression and loneliness situations which are thought to have direct effects on the psychological well-being of high school students; to examine the results mutually: to identify the variables that predict depression and to develop proposals from this point.

Method(s): This research is a descriptive and relational screening model of general screening methods. Survey model is a research approach, aiming to describe the past or present situation as it is, and it is a screening of a whole group of the universe or a group taken from the universe in order to make a general judgment about the universe in an universe composed of a large number of elements. In the general survey model, the situation, person or object which are the subject of the research are defined as being in and of themselves. (Karasar 2014). The study group consists of 270 high school students (159 female 58.9\%, 111 male $41.1 \%$ ) studying at high schools in the province of Van in the fall semester of 2016-2017 academic year. The data obtained from the participants had been transferred to the SPSS statistical package program; then were analyzed with Descriptive, Relational, Two-Step Cluster Analysis and Multinomial Logistic Regression Analysis.

Findings and Discussions: In this study, some variables that may be determinant in the prediction of depression status of high school students have been modeled by Multinominal Logistic Regression Analysis. First, depression-dependent and loneliness-independent variables were subjected to Two-Step Cluster analysis. As a result of the analyzes, it has been seen that $32.2 \%$ of the participants were in low and $20.7 \%$ were in high depression groups in the context of depression scores. The remaining rate was found to be at the middle level (threshold) in depression. For the loneliness scores, it has been observed that $25.2 \%$ of the 
participants had never experienced, $25.2 \%$ had experienced loneliness rarely, $33 \%$ had felt lonely sometimes, and $16.7 \%$ had felt loneliness frequently. At the result of Multinominal Logistic Regression Analysis conducted to determine the predictors that might be effective on the perceptions of the participants, when the "high depression category" was taken as the reference value, the variables in the low depression category are; Mother education level secondary school, mother education level primary school, mother education level nonliterate, loneliness at all, loneliness rarely living, gender female, loneliness sometimes living variables were found significant. In the middle depression category, according to the order of significance: The mother education status primary school, mother education status nonliterate, rarely living loneliness, none living loneliness and sometimes living loneliness variables were found significant. In addition, Pearson correlation test between participants' levels of depression and loneliness showed a significant positive correlation $(\mathrm{r}=.627 ; \mathrm{p} \leq$ $.000)$ over the average. So increase of participants' depression levels raise the status of their loneliness, and the increase of their status of loneliness raise their depression levels.

Conclusions and Recommendations: It was found that there was a positive correlation between depression status and loneliness levels of high school students. As a result of the Multinomial Logistic Regression Analysis, gender, maternal education status and quadruple categorized loneliness variables were found significant on the predicted depression variable. According to these results, family education programs for the development of adolescentfamily relations can be organized in high schools as it coincides with the adolescent high school period. In this context, instead of focusing directly on depression and loneliness feelings, personal guidance activities can be included, such as indirectly expressing feelings and thoughts, developing empathic behaviors, enhancing communication skills, participating in collaborative activities. In addition, high school students can be defined as those who 
YYÜ Eğitim Fakültesi Dergisi (YYU Journal Of EducationFaculty),2017; 14(1):1517-1543, http://efdergi.yyu.edu.tr

experience depression emotionally, and cultural-specific experimental programs with studentschool-family participation can be prepared. It may also be advisable to undertake studies to test and investigate short and long-term effects of these programs. Keywords: High school students, depression, loneliness, logistic regression 